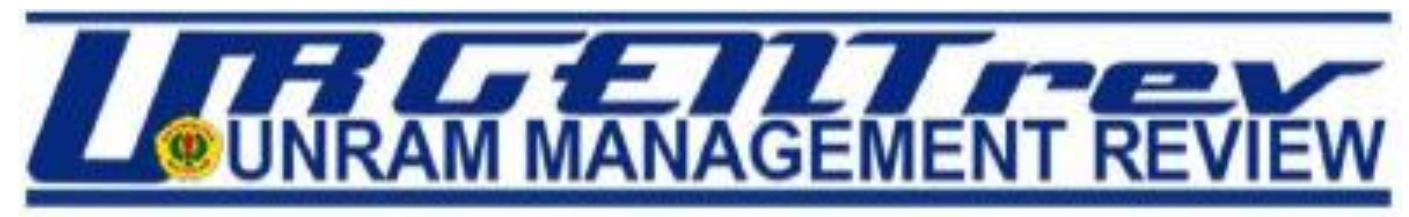

Vol. 1 No. 1 Oktober $2021 \quad$ e.ISSN. 2809-4263

urgentrev.unram.ac.id

\title{
PENGARUH KEMAMPUAN KERJA DAN MOTIVASI KERJA TERHADAP KINERJA KARYAWAN PADA PUSKESMAS DASAN TAPEN KABUPATEN LOMBOK BARAT
}

\author{
Hambawe, Santi Nururly, Muttaqillah \\ Fakultas Ekonomi dan Bisnis \\ Universitas Mataram \\ E-mail: Hambawe2@gmail.com
}

DOI: https://doi.org/10.29303/ju.v1i1.27

\begin{abstract}
ABSTRAK
Penelitian ini bertujuan untuk menguji pengaruh variabel Kemampuan Kerja dan Motivasi Kerja terhadap Kinerja karyawan Pada Puskesmas Dasan Tapen Kabupaten Lombok Barat. Jenis penelitian yang digunakan adalah penelitian asosiatif. Populasi dalam penelitian ini adalah seluruh karyawan Puskesmas Dasan Tapen Kabupaten Lombok Barat, yang berjumlah 55 responden. Alat analisis data dalam penelitian ini menggunakan Analisis Regresi Linier Berganda. Hasil analisis menunjukkan bahwa kemampuan kerja dan motivasi kerja berpengaruh positif dan signifikan terhadap kinerja karyawan pada Puskesmas Dasan Tapen Kabupaten Lombok Barat.
\end{abstract}

Kata Kunci : Kemampuan Kerja, Motivasi Kerja, Kinerja Karyawan.”

\section{ABSTRACT}

This study aims to examine the effect of work ability and work motivation variables on the performance at the Dasan Tapen Health Centre, West Lombok Regency. This type of research is associative research. The population in this study were all employees of the Dasan Tapen Health Centre, West Lombok Regency, totalling 55 respondents. The data analysis tool in thisstudy used Multiple Linear Regression Analysis. The results of the analysis showed that work ability and work motivation had a positive and significant effect on employee performance atthe Dasan Tapen Community Health Centre, West Lombok Regency.

Keywords: Work Ability, Work Motivation, Employee Performance. 


\section{PENDAHULUAN}

\section{A. Latar Belakang}

Sumber Daya Manusia merupakan tokoh sentral di dalam dunia Medis atau dunia kesehatan. Agar aktivitas pelayanan bisa berjalan dengan baik dan lancar, maka tenaga kesehatan / Puskesmas harus memiliki karyawan yang berpengetahuan dan berketerampilan tinggi guna untuk menunjang kinerja yang diharapkan.

Peningkatan kinerja karyawan akan membawa kemajuan bagi sebuah perusahaan atau organisasi untuk dapat bertahan dalam persaingan lingkungan kesehatan yang tidak stabil. Oleh karena itu, upaya peningkatan kinerja karyawan merupakan tantangan manajemen yang sangat serius terhadap Puskesmas Dasan Tapen Kabupaten Lombok Barat karena keberhasilan didalami pencapaian tujuan dan kelangsungan hidup suatu perusahaan atau organisasi sangat bergantung pada kualitas kinerja sumber daya manusianya.

Keberhasilan suatu organisasi atau perusahaan tidak akan lepas dari peran individu yang disebut juga sebagai sumber daya manusia. Mangkunegara (2007 : 2) mengungkapkan bahwa sumber daya manusia adalah perencanaan, pengorganisasian, pelaksanaan dan pengawasan pada pengadaan, pengembangan, pemberian penghargaan. Integrasi, pemeliharaan dan pemisahan tenaga kerja dalam mencapai tujuan organisasi. Dengan adanya sumber daya manusia yang unggul maka akan membuat kinerja karyawan sesuai dengan yang sudah ditetapkan dari perusahaan/ organisasi tersebut.

Kinerja karyawan merupakan hasil kerja dalam arti kualitas dan kuantitas pekerjaan yang dicapai oleh seorang karyawan dalam menjalankan tugasnya sesuai dengan tanggung jawab yang diberikan kepadanya (Mangkunegara, 2007). Hasil kerja setiap karyawan baik kualitas maupun kuantitas kerja sangat menentukan keberhasilan suatu perusahaan/organisasi. Kinerja karyawan yang tinggi dari sumber daya manusia suatu organisasi dapat menjadi keunggulan tersendiri atas perusahaan/organisasi karena tidak mudah ditiru oleh pesaingnya.

Terdapat dua faktor yang mempengaruhi kinerja karyawan yaitu faktor kemampuan dan motivasi (Mangkunegara, 2007). Dengan kemampuan karyawan yang sesuai dengan pekerjaan yang diberikan oleh perusahaan/organisasi dan pemberian motivasi yang baik dari perusahaan/organisasi maka akan tercipta kinerja yang sesuai dengan tujuan yang sudah ditargetkan.

Robbins (2008, 57) menyatakan bahwa kemampuan kerja adalah kemampuan untuk melaksanakan tugas dalam suatu pekerjaan. Kemampuan individu pada dasarnya terdiri dari kemampuan intelektual dan kemampuan fisik. Dengan mengetahui bahwa pekerjaan menuntut kemampuan intelektual dan fisik yang baik, maka setiap karyawan dituntut untuk menyesuaikan pekerjaan sesuai dengan kemampuannya. Karena setiap karyawan memiliki hal yang berbeda dan setiap karyawan memiliki kemampuan yang berbeda, maka kinerja karyawan akan meningkat apabila terdapat kesesuaian kemampuan kerja yang tinggi dan sesuai dengan kemampuan yang dimiliki oleh karyawan itu sendiri.

Puskesmas Dasan Tapen merupakan instansi pemerintah yang bergerak dalam pelayanan kesehatan masyarakat yang berlokasi di Jln. TGH. Abdus Samad, Dasan Tapen Kecamatan Gerung Kabupaten Lombok Barat. Dalam melaksanakan tugas tersebut, setiap karyawan berkewajiban memberikan pelayanan dengan sebaik- baiknya terhadap masyarakat diwilayah tersebut.

Menurut fenomena yang peneliti temukan di lapangan kinerja karyawan pada Puskesmas Dasan Tapen Kabupaten Lombok Barat bisa dikatakan masih lamban di dalam penanganan pasien, bisa dilihat dari jumlah antrian pasien yang panjang dan adanya keluhan dari masyarakat yang 
merasa belum puas dengan pelayanan dari pihak puskesmas itu sendiri dan masih banyaknya jumlah pasien yang belum bisa ditangani dengan baik.

Bila dilihat dari segi kemampuan para karyawan yang ada di lingkup Puskesmas itu bisa dikatakan belum mampu untuk menguasai segala jenis keluhan masyarakat sesuai dengan pernyataan dari Ibu Kepala Puskesmas Dasan Tapen Kabupaten Lombok Barat.

Kemudian bilamana dilihat dari kinerja para karyawannya juga masih kurang, berdasarkan dari nilai SKP yang peneliti dapatkan dari pihak Puskesmas Dasan Tapen Kabupaten Lombok Barat memiliki nilai 45,85 - 52,04. Hal ini disebabkan karena banyak para pasien yang tidak bisa dilayani/tangani dengan baik. Sehingga banyak pasien yang mengeluh dengan pelayanan yang ada di Puskesmas Dasan Tapen tersebut, baik dari ketersediaan obat-obatan maupun hasil kerja saat menangani pasiennya.

Tabel 1. Data Nilai Sasaran Kinerja Pegawai (SKP) Pada Puskesmas Dasan Tapen Kabupaten Lombok Barat

$\begin{array}{cccc}\text { No. } & \begin{array}{c}\text { Jumlah } \\ \text { Karyawan } \\ \end{array} & \begin{array}{c}\text { Nilai } \\ \text { SKP }\end{array} & \begin{array}{c}\text { Jumlah / } \\ \text { Orang }\end{array} \\ \mathbf{1} & \mathbf{3 4}) & & \\ & & 45,85- & 11 \\ & & 49,94 & \text { Orang } \\ & & 50,08- & 23 \\ & & 52,04 & \text { Orang }\end{array}$

Keterangan :

$\begin{array}{ll}91-10 & \text { Amat baik } \\ 76-90 & \text { Baik }\end{array}$
$61-75$
Cukup
$51-60$
Sedang
$<50$
Kurang

Bila dilihat dari motivasi kerja para karyawan juga masih tergolong rendah karena masih banyak karyawan yang sering tidak masuk kerja dan tidak mau mencoba bahkan tidak memiliki semangat untuk menangani hal/jenis penyakit baru yang dialami oleh pasien sehingga kebanyakan dari masyarakat memilih ke rumah sakit untuk berobat.

Sehingga berdasarkan uraian teori dan fenomena yang terjadi di lokasi penelitian, peneliti merasa tertarik untuk melakukan penelitian dengan Judul : " Pengaruh Kemampuan Kerja dan Motivasi Kerja Terhadap Kinerja Karyawan Pada Puskesmas Dasan Tapen Kabupaten Lombok Barat".

\section{B. Perumusan Masalah}

"Berdasarkan latar belakang dan identifikasi masalah di atas, maka perumusan masalah pada penelitian ini adalah sebagai berikut :"
1. Apakah kemampuan kerja berpengaruh terhadap kinerja Karyawan Puskesmas Dasan Tapen?

2. Apakah Motivasi kerja berpengaruh terhadap kinerja Karyawan Puskesmas Dasan Tapen?

3. Apakah kemampuan kerja dan Motivasi kerja berpengaruh terhadap kinerja Karyawan Puskesmas Dasan Tapen?

\section{KAJIAN PUSTAKA \\ Kinerja}

"Menurut (Robbins, 2006) kinerja adalah pencapaian yang optimal sesuai dengan" potensi yang dimiliki seorang karyawan merupakan hal yang selalu menjadi perhatian bagi pemimpin 
organisasi." Kinerjah ini menggambarkan sejauh manah aktivitas seseorang dalam menjalankan tugas dan berusaha mencapai tujuan yang telah ditetapkan.

Indikator untuk mengukur kinerja karyawan yaitu :

1. Kualitas kerja

Kualitas kerja merupakan kualitas kerja diukur dari persepsi karyawan terhadap kualitas pekerjaan yang dihasilkan serta kesempurnaan tugas terhadap keterampilan dan kemampuan karyawan.

2. Kuantitas

Kuantitas adalah jumlah yang diproduksi yang dinyatakan dalam istilah seperti jumlah unit, jumlah siklus aktivitas yang diselesaikan.

3. Ketepatan waktu

“ Ketepatan waktu adalah tingkat kegiatan yang diselesaikan di awal waktu yang ditentukan, dilihat dari sudut" koordinasi dengan hasil keluaran dan memaksimalkan waktu yang tersedia untuk kegiatan lain."

4. Kemandirian

Kemandirian adalah tingkat dimana seorang pegawai yang nantinya akan mampu menjalankan fungsi pekerjaannya. Komitmen kerja merupakan tingkatan dimana karyawan memiliki komitmen kerja terhadap instansi dan tanggung jawab karyawan atas pekerjaannya.

\section{Kemampuan Kerja}

Menurut Soelaiman (2007:112) kemampuan kerja adalah " sifat yang dibawa dari sejak lahir" atau dapat dipelajari untuk memungkinkan seseorang dapat menyelesaikan pekerjaannya, baik secara mental ataupun fisik."
Indikator untuk mengukur kemampuan kerja menurut Rahardjo dkk (2016) yaitu :

1. Pengetahuan (Knowledge)

Pengetahuan adalah fondasi yangdi atasnya keterampilan dan kemampuan dibangun. Pengetahuan yang terorganisir tentang informasi, fakta, prinsip atau prosedur yang jika diterapkan menghasilkan kinerja pekerjaan yang memadai.

\section{Pelatihan (Training)}

"Pelatihan adalah pendidikan jangka pendek yang menggunakan prosedur yang sistematis dan" terorganisir sehingga pekerja non manajerial mempelajari" pengetahuan dan keterampilan teknis untuk tujuan tertentu."

3. Pengalaman (Experience)

Pengalaman adalah tingkat penguasaan pengetahuan dan keterampilan seseorang dalam pekerjaannya yang dapat diukur dari massa kerja serta tingkat pengetahuan dan keterampilan yang dimiliki.

4. Keterampilan (Skill)

Keterampilan adalah kemampuan seseorang" dalam menguasai pekerjaan, alat dan mesin tanpa mengalami kesulitan."

5. Kesanggupan Kerja

Kesanggupan kerja adalah suatu kondisi dimana seorang karyawan merasa mampu untuk menyelesaikan pekerjaan yang diberikan.

\section{Motivasi Kerja}

Motivasi kerja adalah dorongan, upaya dan keinginan yang ada dalam diri manusia yang mengaktifkan, memberi daya serta mengarahkan perilaku dalam melaksanakan tugas di lingkungan pekerjaannya (Rivai,2001). 
Indikator untuk mengukur Motivasi kerja menurut Frederik Herzberg dalam Notoatmodjo (2009) yaitu :

\section{Prestasi (Achievement)}

Setiap orang tentu menginginkan" keberhasilan dalam tugas yang dilaksanakan. Pencapaian prestasi atau keberhasilan dalam melakukan suatu pekerjaan akan menggerakkan yang bersangkutan untuk melakukan tugas-tugas berikutnya.

\section{Pengakuan (Recognition)}

Pengakuan prestasi merupakan alat motivasi yang ampuh, bahkan bisa melebihi kepuasan yang ada di dalam kompensasi. Sumber pengakuan dapat berasal dari atasan, manajemen dan publik. Oleh karena itu seseorang yang memperoleh pengakuan dapat meningkatkan semangat karyawan itu dalam bekerja. Pengakuan dapat berupa pujian, tanggapan pada tugas yang dilakukan dengan baik atau kenaikan gaji khusus bagi karyawan.

3. Pekerjaan itu sendiri (The work it self)

Pekerjaan atau tugas yang menarik dan memiliki nilai tantangan bagi pegawai merupakan faktor motivasi. Suatu tugas akan disenangi oleh seorang karyawan apabila pekerjaan itu sudah sesuai dengan keterampilan dan kemampuannya. Karyawan cenderung menyukai pekerjaan yang sifatnya menarik dan bukan rutin.

4. Kemajuan (Advancement)

Peluang untuk maju merupakan pengembangan potensi diri seseorang karyawan dalam melakukan pekerjaan. Setiap karyawan tentunya menghendaki kemajuan atau perubahan dalam pekerjaannya yang tidak hanya dalam hal jenis pekerjaan yang berbeda atau bervariasi, tetapi juga posisi yang lebih baik. Setiap karyawan menginginkan kenaikan jabatan yang lebih tinggi, mendapatkan kesempatan untuk meningkatkan pengalaman mereka di tempat bekerja. Peluang bagi pengembangan kemampuan diri akan menimbulkan kepuasan dan motivasi tersendiri bagi karyawan untuk bekerja lebih giat.

5. Pengembangan potensi individu (The possibility of growth)

Kemungkinan pertumbuhan ini bukan saja peningkatan seseorang di dalam organisasi tetapi juga situasi dimana seseorang dapat meningkatkan keterampilan dan keahliannya misalnya melalui pelatihan khusus dan melanjutkan ke jenjang pendidikan yang lebih tinggi.

\section{METODE PENELITIAN Jenis Penelitian}

Berdasarkan Permasalahan yang akan diteliti tentang "Pengaruh Kemampuan Kerja dan Motivasi Kerja Terhadap Kinerja Karyawan Pada Puskesmas Dasan Tapen Kabupaten Lombok Barat" merupakan hubungan fungsional atau hubungan pengaruh, karena apabila seorang karyawan memiliki kemampuan kerja maka akan menghasilkan kinerja yang baik dan begitu juga sebaliknya apabila seorang karyawan tidak memiliki kemampuan kerja maka akan menghasilkan kinerja yang buruk. Seorang karyawan yang memiliki motivasi tinggi akan menghasilkan kinerja yang baik, begitu juga sebaliknya apabila karyawan tidak memiliki motivasi maka akan menghasilkan kinerja yang buruk pula. Seorang karyawan yang memiliki kemampuan dan motivasi/dorongan yang kuat pada dirinya akan menyebabkan kinerja yang sangat baik.

Permasalahan ini sifat hubungan antar variabelnya adalah saling berhubungan antara satu variabel dengan variabel lainnya. Sifat hubungan masalah seperti ini cocok jika diteliti menggunakan 
Jenis penelitian asosiatif. Penelitian asosiatif merupakan penelitian yang bermaksud menggambarkan dan menguji hipotesis hubungan dua variabel atau lebih (Sugiyono,2014:69). Variabel yang akan diuji pengaruhnya adalah Kemampuan kerja dan motivasi kerja terhadap kinerja karyawan pada Puskesmas Dasan Tapen Kabupaten Lombok Barat.

\section{Lokasi Penelitian}

Penelitian ini di lakukan di Puskesmas Dasan Tapen Kabupaten Lombok Barat di Jln. TGH. Abdus Samad Kecamatan Gerung, Kabupaten Lombok Barat dengan mempertimbangkan sebagaiberikut:

a. Ketersediaan data yang dibutuhkan oleh peneliti

b. Kesediaan pihak terkait dalam memberikan data-data tersebut bagi penelitian ini.

c. Adanya masalah yang sesuai dengan objek penelitian.

d. Peneliti ingin membuktikan bagaimana kinerja karyawan pada Puskesmas Dasan Tapen, berkenaan dengan tingkat kemampuan dan motivasi yang ada pada lingkup Puskesmas Tersebut.

\section{Metode Pengumpulan Data}

Metode pengumpulan data yang dipakai untuk" penelitian ini adalah metode sensus." Metode sensus adalah metode pengumpulan data yang dilakukan terhadap seluruh populasi yang cirinya hendak diketahui, Jadi, data yang diperoleh dapat menunjukkan ciri keseluruhan populasi yang sebenarnya. Menurut Sugiyono (2008:78) sensus adalah suatu teknik penentuan sampel bila semua anggota populasi digunakan sebagai sampel.

\section{Populasi penelitian}

Populasi dalam penelitian ini adalah keseluruhan karyawan yang bekerja pada Puskesmas Dasan Tapen Kabupaten Lombok Barat yang berjumlah 55 Orang yang terdiri dari Pegawai ASN sebanyak 34 dan Kontrak BLUD sebanyak 21 Orang.

\section{Teknik dan Alat Pengumpulan Data}

"Teknik pengumpulan data yang dipakai" untuk penelitian ini yaitu:"
a. Angket
b. Wawancara

\section{Analisis Regresi Linier Berganda}

Menurut Sugiyono (2012:277) analisis regresi linier berganda digunakan oleh peneliti, bila peneliti bermaksud meramalkan bagaimana keadaan (naik turunnya) variabel dependen, bila dua atau lebih variabel independen sebagai faktor predikator dimanipulasi ( dinaik turunkan nilainya ). Untuk memprediksi nilai sebuah variabel dependen dari nilai beberapa variabel independen.

Analisis ini dilakukan untuk mengetahui besarnya pengaruh variabel bebas terhadap variabel terikat. Apabila hasil perhitungan koefisien regresi berganda positif, berarti variabel bebas mempunyai pengaruh terhadap variabel terikat.

Adapun Formulasi dari regresi linier berganda yaitu:

$$
\mathrm{Y}=a+\beta_{1} X_{1}+\beta_{2} X_{2}+e
$$

Dimana :

$$
\begin{array}{ll}
\mathrm{Y} & =\text { Kinerja } \\
\beta_{1} \beta_{2} & =\text { Koefisien Regresi } \\
a & =\text { Konstanta } \\
\mathrm{e} & =\text { Standar Eror } \\
X_{1} & =\text { Kemampuan Kerja } \\
X_{2} & =\text { Motivasi Kerja }
\end{array}
$$


HASIL DAN PEMBAHASAN

Analisis Regresi Linier Berganda.

Berdasarkan uji yang telah dilakukan, persamaan regresi yang diketahui adalah :

$\mathrm{Y}=1,314+0,570 \mathrm{X}_{1}+0,495 \mathrm{X}_{2}+\mathrm{e}$

4.1 Keterangan:

4.2 Konstanta $(\alpha)=1,314$

$4.3 \mathrm{~b}_{1}=0,570$

$4.4 \mathrm{~b}_{2}=0,495$

4.5 $\mathrm{X}_{1}=$ Kemampuan Kerja

4.6 $\mathrm{X}_{2}=$ Motivasi Kerja

4.7 $\mathrm{E}=$ Standar Error

- $\alpha=1,314$

Konstanta sebesar 1,314 artinya jika variabel Kemampuan Kerja $\left(\mathrm{X}_{1}\right)$ dan Motivasi Kerja $\left(\mathrm{X}_{2}\right)$ adalah 0, maka kinerja nilainya 1,314 dengan asumsi variabel-variabel lain yang dapat mempengaruhi Kinerja Karyawan dianggap tetap.

- $\beta_{1}=0,570$

Berdasarkan pada persamaan regresi linier berganda tersebut diperoleh variabel Kemampuan Kerja $\left(X_{1}\right)$ positif sebesar 0,570 yang berarti bahwa setiap peningkatan satu satuan variabel Kemampuan Kerja terjadi peningkatan Kinerja Karyawan Puskesmas Dasan Tapen sebesar 0,570 satuan dengan asumsi bahwa variabel lain tidak berubah atau tetap. Koefisien regresi yang bertanda positif menunjukkan bahwa terdapat pengaruh yang searah antara variabel
Kemampuan Kerja terhadap Kinerja Karyawan. Sehingga dapat dinyatakan" bahwa hipotesis pertama diterima."

- $\beta_{2}=0,495$

Berdasarkan pada persamaan regresi linier berganda tersebut diperoleh variabel Motivasi Kerja $\left(\mathrm{X}_{2}\right)$ positif sebesar 0,495 yang berarti bahwa setiap peningkatan satu satuan variabel Kemampuan Kerja maka peningkatan Kinerja Karyawan Puskesmas Dasan Tapen sebesar 0,495 satuan dengan asumsi bahwa variabel lain tidak berubah atau tetap. Koefisien regresi yang bertanda positif menunjukkan bahwa terdapat pengaruh yang searah antara Motivasi Kerja terhadap Kinerja Karyawan .Sehingga dapat dinyatakan bahwa hipotesis kedua diterima.

\section{Hasil Uji Signifikan Parameter Individual (Uji Statistik t Parsial)}

Terdapat dua hipotesis (Ha)" yang diajukan dalam uji t ini” :

$\mathrm{H} 1$ = Kemampuan Kerja (X1) berpengaruh positif dan signifikan terhadap Kinerja Karyawan (Y). Dilihat dari hasil pengujian diperoleh nilai t-hitung sebesar $2.608>$ t-tabel 2,007 dan nilai signifikansi $0,012<0,05$. Maka dapat disimpulkan bahwa $\mathrm{H}_{0}$ ditolak dan $\mathrm{H}_{1}$ diterima dan nilai $\mathrm{t}$ positif menunjukkan bahwa kemampuan kerja mempunyai hubungan yang searah dengan kinerja karyawan pada Puskesmas Dasan Tapen. Jadi dapat disimpulkan bahwa kemampuan kerja berpengaruh positif dan signifikan terhadap kinerja karyawan pada Puskesmas Dasan Tapen. Artinya jika kemampuan kerja karyawan semakin tinggi maka dipastikan kinerja karyawan dalam bekerja di Puskesmas semakin tinggi juga.

$\mathrm{H} 2=$ Motivasi Kerja (X2) berpengaruh positif dan signifikan terhadap Kinerja Karyawan (Y). Dilihat dari hasil pengujian diperoleh nilai thitung sebesar 3,517>t- tabel 2,007 dan nilai signifikansi 
$0,01<0,05$. Maka dapat disimpulkan bahwa $\mathrm{H}_{0}$ ditolak dan $\mathrm{H}_{1}$ diterima dan nilai t positif menunjukkan bahwa motivasi kerja memiliki hubungan yang searah dengan kinerja karyawan pada Puskesmas Dasan Tapen. Jadi dapat disimpulkan bahwa motivasi kerja berpengaruh positif dan signifikan terhadap kinerja karyawan pada Puskesmas Dasan Tapen. Artinya jika tingkat motivasi kerja karyawan tinggi maka kinerja karyawan akan semakin tinggi juga karena pekerjaan yang dibebankan dapat terlaksana dengan baik.

\section{Hasil Uji Koefisien Determinasi $\left(\mathbf{R}^{\mathbf{2}}\right)$}

Nilai $R$ Square adalah sebesar 0,576 atau $57,6 \%$ yang artinya variabel kinerja karyawan dapat dijelaskan sebesar $57,6 \%$ oleh kemampuan kerja dan motivasi kerja. Selisihnya sebesar 42,4\% (100\% $57,6 \%$ ) dijelaskan oleh faktor atau variabel lain yang tidak diketahui dan tidak termasuk dalam analisis regresi ini seperti Kepemimpinan, tata pengelolaan, Kepuasan dan lain-lain.

\section{Interpretasi Hasil Penelitian}

Berdasarkan analisis regresi linier berganda yang telah dilakukan, hasil penelitian menunjukkan bahwa Kemampuan kerja berpengaruh positif dan signifikan terhadap Kinerja karyawan Puskesmas Dasan Tapen Kabupaten Lombok Barat. Hal ini membuktikan bahwa hipotesis pertama diterima. Skor tertinggi jawaban responden terkait kemampuan kerja berada pada indikator pengetahuan yaitu berdasarkan pendidikan dan penempatan pada bidang pekerjaan karyawan sudah sangat sesuai dengan latar belakang pendidikannya. Artinya dengan adanya pengetahuan yang dimiliki oleh karyawan Puskesmas Dasan Tapen, bisa menjadi fondasi awal di dalam meningkatkan kinerja karyawan dalam melaksanakan dan menyelesaikan tugas yang diberikan oleh pihak Puskesmas Dasan Tapen dengan baik.

Berdasarkan analisis regresi linier berganda yang telah dilakukan, hasil penelitian menunjukkan bahwa Motivasi kerja berpengaruh positif dan signifikan terhadap Kinerja karyawan Puskesmas Dasan Tapen Kabupaten Lombok Barat. Hal ini membuktikan bahwa hipotesis Kedua diterima. Skor tertinggi jawaban responden terkait motivasi kerja berada pada indikator pengembangan potensi yaitu setiap karyawan memiliki kesempatan untuk meningkatkan keterampilan dan keahlian yang dimiliki di dalam melaksanakan tugas .Artinya dengan adanya kesempatan untuk pengembangan potensi bagi karyawan Puskesmas Dasan Tapen ini maka akan meningkatkan keterampilan dan keahlian yang dimilikinya sehingga kinerja karyawan juga meningkat.

\section{KESIMPULAN}

Berdasarkan hasil kajian setelah menganalisis dan menguji pengaruh kemampuan kerja dan motivasi kerja terhadap kinerja karyawan pada Puskesmas Dasan Tapen Kabupaten Lombok Barat, maka dapat disimpulkan sebagai berikut :

1. Variabel kemampuan kerja berpengaruh positif dan signifikan terhadap kinerja karyawan pada Puskesmas Dasan Tapen. Artinya jika setiap karyawan memiliki kemampuan kerja yang tinggi maka kinerja karyawan akan semakin tinggi juga.

2. Variabel motivasi kerja berpengaruh positif dan signifikan terhadap kinerja karyawan pada Puskesmas Dasan Tapen. Artinya semakin tinggi motivasi yang dimiliki oleh setiap karyawan maka kinerja karyawan semakin tinggi.

\section{DAFTAR PUSTAKA}

Prawirosentono, S., 1999, Kebijakan Kinerja Karyawan, BPFE, Yogyakarta.

Handoko, T. Hani. 1994. Manajemen Personalia dan Sumber Daya Manusia, Yogyakarta: BPFE. 
Ika Ruhana . 2015. "Pengaruh Kemampuan Kerja dan Motivasi Kerja" Terhadap Kinerja Karyawan." Skripsi Program S1 Ilmu Administrasi Universitas Brawijaya.

Ika Rahmatika, 2014. Pengaruh

Kemampuan dan Motivasi Kerja Terhadap Kinerja Karyawan (Studi di Bank BNI Syariah Cabang Bogor), Skripsi, Fakultas Syariah dan Hukum UIN Syarif Hidayatullah Jakarta.

Kristiani. 2013. "Pengaruh Kemampuan Kerja dan Motivasi Kerja" Terhadap Kinerja Karyawan." Skripsi S1 Universitas Diponogoro.

Kus Haryanto, 2009. Pengaruh Motivasi dan Kompetensi Terhadap Kinerja Individual Guru (Studi Pada SMPN 3 Tanjung Lombok Timur), Skripsi, Fakultas Ekonomi Universitas Mataram.

Mathis R. L dan Jackson J. H, 2002, Manajemen Sumber Daya Manusia, Salemba Empat. Jakarta.

Mangkunegara, Anwar, P. 2007. Manajemen Sumber Daya Manusia Perusahaan. Bandung : Remaja Rosadakarya. Edisi IV.

Mukarromah, 2003. Analisis Pengaruh Faktor-Faktor Motivasi Kerja Terhadap Prestasi Kerja Karyawan (Studi Pada Kantor Depok Logistik Nusa Tenggara Barat), Skripsi Fakultas Ekonomi : Universitas Mataram.

Nurmayunita. 2015. "Pengaruh Kemampuan" dan Motivasi Kerja Terhadap Kinerja Perawat." Skripsi S1 Poltekes Rs. Dr. Soepraone.

Robbins, Stephen dan Timothy A. Judge. 2008 Perilaku Organisasi, Edisi 16 Jakarta Salemba Empat.

2006. Perilaku

Organisasi, Jakarta : PT. Indeks, Kelompok Gramedia. 2003. Organizational

Behaviour,8th Edition. New Jersey.

Siagian, Sondang P. 1997, Teori dan Praktek Kepemimpinan, Rineka Cipta, Jakarta.
Simamora, Henry, 2001. Manajemen Sumber Daya Manusia, Edisi Kedua,Yogyakarta: YKPN.

Sugiyono 2014.Metode Penelitian Manajemen. Bandung Alfabeta.

2011. Metode Penelitian

Kuantitatif, Kualitatif dan $R \& D$. Bandung Alfabeta.

Zulkhairi, 2002. Motivasi dan Kemampuan Kerja Terhadap Prestasi Kerja Karyawan Bagian Sales Force Pada PT. Columbindo Perdana Sub Mataram, Skripsi Fakultas Ekonomi : Universitas Mataram 